LVOV MATHEMATICAL SCHOOL

IN THE PERIOD 1915-45 AS SEEN TODAY

BANACH CENTER PUBLICATIONS, VOLUME 87

INSTITUTE OF MATHEMATICS

POLISH ACADEMY OF SCIENCES

WARSZAWA 2009

\title{
IDEAS OF HUGO STEINHAUS IN CONTEMPORARY MATHEMATICS
}

\author{
YURI B. ZELINSKII \\ Institute of Mathematics \\ National Academy of Sciences of Ukraine \\ UA-01601 Kyiv, Ukraine
}

The easiest way to obtain a sphere is by blowing a soap bubble. Hugo Steinhaus, "Mathematical Snapshots" ("Kalejdoskop matematyczny”)

Hugo Steinhaus was born on 14 January 1887 in Jasło, Galicia, Austrian Empire (now Poland) into a family of Jewish intellectuals. By the time Steinhaus' was born, Austria had named the region the Kingdom of Galicia and Lodomeria and given it a large degree of administrative autonomy. Steinhaus' uncle was a politician in the Austrian parliament.

Steinhaus began studies for one year in L'viv, spent one term in Munich and then five years studying mathematics at the University of Göttingen. There Carathéodory, Courant, Hilbert, Klein, Koebe, Runge, Toeplitz, and Zermelo influenced him. He completed his doctoral thesis Neue Anwendungen des Dirichletschen Prinzips under Hilbert's supervision (1911) with distinction. But the main influence in the direction of Steinhaus' research is due to Lebesgue's two books Leçons sur l'intégration et la recherche des fonctions primitives (1904) and Leçons sur les séries trigonométriques (1906).

After military service in the Polish Legion at the beginning of World War I, Steinhaus lived in Kraków. Steinhaus took up an appointment as an assistant at the Jan Kazimierz University in L'viv and, around 1920, he was promoted to extraordinary professor. The 1920 s and the 1930s witnessed a very successful development of mathematics at the L'viv University. Scholars of prominence such as W. Sierpiński, H. Steinhaus, S. Ruziewicz, E. Żyliński, S. Banach, W. Nikliborc, J. Schauder, S. Kaczmarz, W. Orlicz, H. Auerbach and S. Mazur lectured here. The L'viv School of Mathematics, founded by Steinhaus and Banach, concentrated mainly on functional analysis and its diverse applications, the general theory of orthogonal series, and probability theory. Steinhaus was the main figure

2000 Mathematics Subject Classification: 58C99, 97A30, 01A70.

The paper is in final form and no version of it will be published elsewhere. 
in the L'viv School until 1941. In 1923 he published in Fundamenta Mathematicae the first rigorous account of the theory of tossing coins based on measure theory. In 1925 he was the first to define and discuss the concept of strategy in game theory. Steinhaus published his second joint paper with Banach in 1927 Sur le principe de la condensation des singularités. In 1929 he started a new journal Studia Mathematica (together with Stefan Banach) and by himself Zastosowania matematyki (The Applications of Mathematics, 1953). Another important publishing venture, in which Steinhaus was involved, begun in 1931, was a new series of Mathematical Monographs. The series was set up under the editorship of Steinhaus and Banach from L'viv and Knaster, Kuratowski, Mazurkiewicz, and Sierpiński from Warsaw. An important contribution to the series was a volume written by Steinhaus jointly with Kaczmarz The Theory of Orthogonal Series (Theorie der Orthogonalreihen 1937). Steinhaus is well known for his book Mathematical Snapshots (1937). To Steinhaus mathematics was a mirror of reality and life much in the same way as poetry is a mirror, and he liked to "play" with numbers, sets, and curves, the way a poet plays with words, phrases, and sounds.

The mathematicians of the L'viv School did a great deal of mathematical research in the cafeterias of L'viv. The Scottish Café was the most popular with the mathematicians in general but not with Steinhaus who (according to Ulam): - ... usually frequented a more genteel teashop that boasted the best pastry in Poland. This was Ludwik Zalewski's Confectionery at 22 Akademicka Street. It was in the Scottish Café, however, that the famous Scottish Book consisting of open questions posed by the mathematicians working there came into being. Steinhaus, who sometimes joined his colleagues in the Scottish Café, contributed ten problems to the book, including the final one written on 31 May 1941 only a few days before the Nazi troops entered the town. Steinhaus spent the war years from June 1941 hiding from the Nazis, suffering great hardships, going hungry most of the time but always thinking about mathematics. After the liberation of Poland he moved to Wrocław (1945) and started with the usual energy renewing the former strength of the mathematical school, which would be appropriate to call a continuation of the L'viv Mathematical School. In doing so he was counting on the gifted young people that came to Wrocław University. To considerable extent he managed to put his idea into practice and Wrocław became a mathematical centre. He made several visits to universities in the United States. After the end of World War II he sent the Scottish Book, which was preserved by him through the war, to Ulam in the United States. The book was translated into English by Ulam and published. Steinhaus, then in the University of Wrocław, decided that the tradition of the Scottish Book was too good to end. In 1946 he extended the L'viv tradition to Wrocław starting the New Scottish Book. Steinhaus was professor of Wrocław University (1945-1961) and then University of Notre Dame (Indiana, USA, 1961-1962), University of Sussex (1966), member of PAU (Polish Academy of Abilities, since 1945) and PAN (Polish Academy of Sciences, since 1952), and many international science societies and science academies. Steinhaus' bibliography contains 170 items. He died 25.02.1972 in Wrocław.

Let us finally examine some of Steinhaus' mathematical contributions that we have not mentioned above. 
1. In 1944 Steinhaus proposed the problem of dividing a cake into $n$ pieces so that it is proportional (each person is satisfied with his share) and envy free (each person is satisfied - nobody receives more than a fair share). For $n=2$ the problem is trivial, one person cuts the cake, the other chooses his piece. Steinhaus found a proportional but not envy free solution for $n=3$. An envy free solution to Steinhaus's problem for $n=3$ was found in 1962 by John H. Conway and, independently, by John Selfridge. For general $n$ Steven Brams and Alan Taylor solved the problem in 1995.

2. On the plane there is a circle $S$. An arc lying in the domain bounded by $S$ connects each pair of antipodal points of $S$. These arcs depend continuously on their ends. Obviously, any two different arcs intersect. Do there exist everywhere three different arcs having a point in common?

This problem was raised by H. Steinhaus in 1953. In 1958 A. Kosiński proved a theorem from which a positive answer follows. The cited theorem is more general:

(a) The circle $S$ is replaced by an $n$-sphere in the Euclidean $(n+1)$-space;

(b) The arcs are replaced by arbitrary acyclic continua;

(c) Continuity is meant in a less restrictive sense, namely that of the upper semicontinuity.

Under these assumptions Kosiński has proved that there exist three continua having a common point. (For $n>1$ even the existence of two intersecting arcs is not obvious.) What is more, he proved that the closure of the set of points at which at least three continua intersect has dimension at least $n-1$ under the assumption that each point of the ball bounded by $S^{n-1}$ belongs to at most finitely many continua. However, in all known examples the dimension of the set of these points is precisely equal to $n$ (i.e., this set contains an open $n$-ball). Therefore, Kosiński posed the question whether the dimension of the set of points at which at least three continua intersect is always equal to $n$ under the assumption that at each point only finitely many of the connecting continua intersect.

In [6] a positive answer to this question was obtained even under more general assumptions.

Let $F$ be a family of continua. We say that a point $a \in Y$ is of order $N$ ( $N$ being any cardinal) $\operatorname{ord}_{F}(a)=N$, if $a$ belongs to exactly $N$ distinct elements of $F$. Let

$$
N(F)=\max _{a \in Y} \operatorname{ord}_{F}(a) .
$$

Suppose that $F$ is a family of the above continua. Let $F_{0}$ be a similar family of continua in $\mathbb{R}^{n}$. From Kosiński result follows that $N(n, F) \geq 3$ and $N\left(n, F_{0}\right) \geq 2$. Consider now the question of exact value of $N(n, F)$ and $N\left(n, F_{0}\right)$. Kosiński's estimates are the following:

$$
3 \leq N(n, F) \leq 2 n-1 ; \quad 2 \leq N\left(n, F_{0}\right) \leq 2 n-2 \quad \text { and } \quad N\left(n, F_{0}\right) \leq N(n, F) .
$$

In [7] examples were constructed giving the exact values: $N(n, F)=3$ and $N\left(3, F_{0}\right)=$ 2. It was shown that for an arbitrary sphere it is possible to arrange the indicated joining 
of antipodal points by arcs in such a way that no more than three arcs can pass through every point.

A closely related question can be formulated as follows: Consider a mapping $f$ of the 2-dimensional Möbius band $M$ into 2-cell $Q$, and suppose that $f$ maps homeomorphically the boundary of $M$ onto the boundary of $Q$. Do there exist three different points of $M$ which have a common image under $f$ ?

A. Kosiński (1958) gave a positive answer to that question, even generalized to higher dimensions. Yet in the case when $f$ is not a homomorphism on the boundary (even of degree 1) the question remains open.

Yu. B. Zelinskii (1975) gives an answer for every mapping of a domain of odd degree: THeOREM 1. Let $f: \bar{D} \rightarrow \bar{D}_{1}$ be a continuous mapping ( $D$ and $D_{1}$ are open domains in the respective manifolds $M^{n}$ and $N^{n}$ ) such that

1. $f(\partial D) \cap f(D)=\emptyset$, and

2. $H_{c}^{n-1}\left(\partial D ; \mathbb{Z}_{2}\right) \neq 0$ and the mapping $f^{*}: H_{c}^{n-1}\left(f \partial D ; \mathbb{Z}_{2}\right) \rightarrow H_{c}^{n-1}\left(\partial D ; \mathbb{Z}_{2}\right)$ induced by the restriction $\left.f\right|_{\partial D}$ is an epimorphism.

Then either $\left.f\right|_{D}$ is a homeomorphism, or there is a point $y \in \operatorname{Int} D_{1}$ having at least three preimages in D. Yet, if the mapping $f$ is zero-dimensional, then in the latter case the set $A=\left\{y \mid f^{-1} y\right.$ consists of at least three points $\}$ has dimension $n$.

THEOREM 2. Every proper mapping of a domain of an $n$-dimensional manifold onto a domain of another $n$-dimensional manifold of degree $k$ either is the interior mapping or there exists a point in the image that possesses not less than $|k|+2$ original preimages. If the restriction of $f$ to the interior of the domain is zero-dimensional mapping, then in the latter case mentioned above, a set of points of image which do not possess less than $|k|+2$ original preimages contains a subset of complete dimensionality $n$.

\section{Unsolved problems}

1. What is the exact value of $N\left(n, F_{0}\right)$ for $n \geq 4$ : two or three?

2 . Does there exist a mapping of the $n$-dimensional projective space on an $n$-dimensional sphere such that every point of the image has no more than three preimage points for $n \geq 3$ ?

3. Does there exist a mapping of the $n$-dimensional projective space in an $n$-dimensional sphere such that every point of the image has no more than two preimage points for $n \geq 3$ ?

4. Do there exist for every proper mapping $f: \bar{D} \rightarrow \bar{D}_{1}\left(D, D_{1}\right.$ being domains of $n$-dimensional manifolds) a proper mapping $g$ homotopical to $f$ such that every point of the image $g(D)$ has no more than $|\operatorname{deg} f|+2$ preimage points?

Application. Hugo Steinhaus data form filled on December 22, 1939. ${ }^{1}$

\footnotetext{
${ }^{1}$ Editor's remark. Note that the Soviet document (item no. 12) classifies both Polish and Ukrainian languages as languages of Soviet nations.
} 
to oсn6. споави Do sprawy personalnej
Iрозетарі neix враїп, cxnaiseeg!

Proletariusze wszystkich krajów lączcie się!

\section{Особистий листок по обліку кадрів}

osobowa karta ewideneyjna kadrów

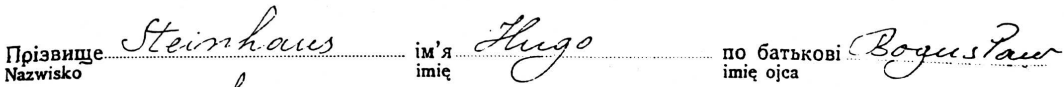

1. Cтать $2 x y-\sigma h c$

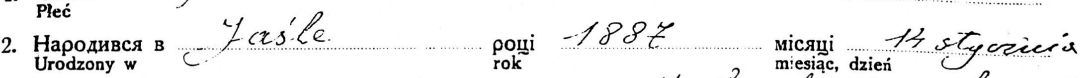
Urodzony $w$ rok miesiąc, dzień

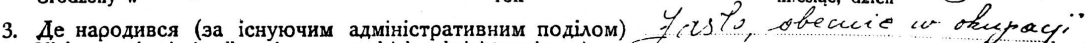
Miejsce urodzenia (wedlug obecnego podzialu administracyjnego) ctiecuiechicy

4. Напіональність Narodowość

5. Основна професія (звання) до початку педагогічної роботи Glówny zawód (zatrudnienie) przed rozpoczęciem pracy pedagogicznej

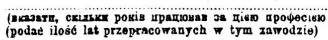

6. Чи перебував в партіях (яких, де, з якого і по якій час) Czy nalezial do partyj (jakich, gdzie, od kiedy, do kiedy)

$$
\text { nie zafeidt do zaolue croxiz: }
$$

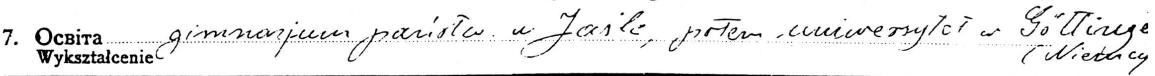

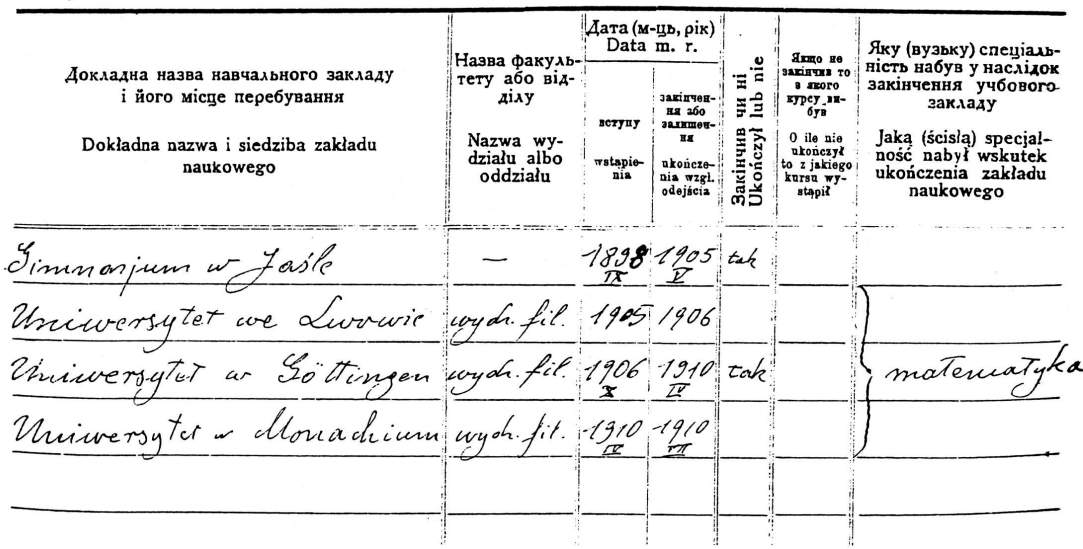

8. Учена ступінь (кандидат, доктор наук) й учене звання (доцент, професор) ступені і званв Stopien naukowy (kandydat, doktor nauk I tytul naukowy) (docent, profesor) stopnie i tytuly

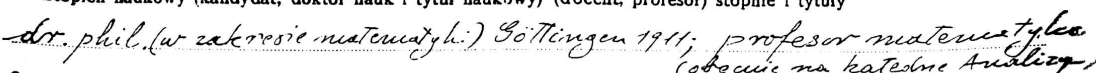

9. Чи має наукові прауі та винаходи .................. (перелік наукових прауь та винаходів 3 заэна-

ченням, по яких питаннях і де опубліковано, необхідно дати в додатку).

Czy ma prace naukowe i czy dokonal wynalazków (tuk jab nio). (wyliczenie prac naukowych i wynalazków z wyszear gólnieniem badanych zagadnień, czy i gdzie opublikow al swoje prace, koniecznie podać w załączniku).

spis proc ar osobuy we zat a cucitur

Fig. 1. Document 1 
10. Виковувана робота 3 початку трудової діяльності (включаючи війскову службу) Praca wyjkcny:wana od początku zatrudnienia (wliczając slużbę wojskowa)

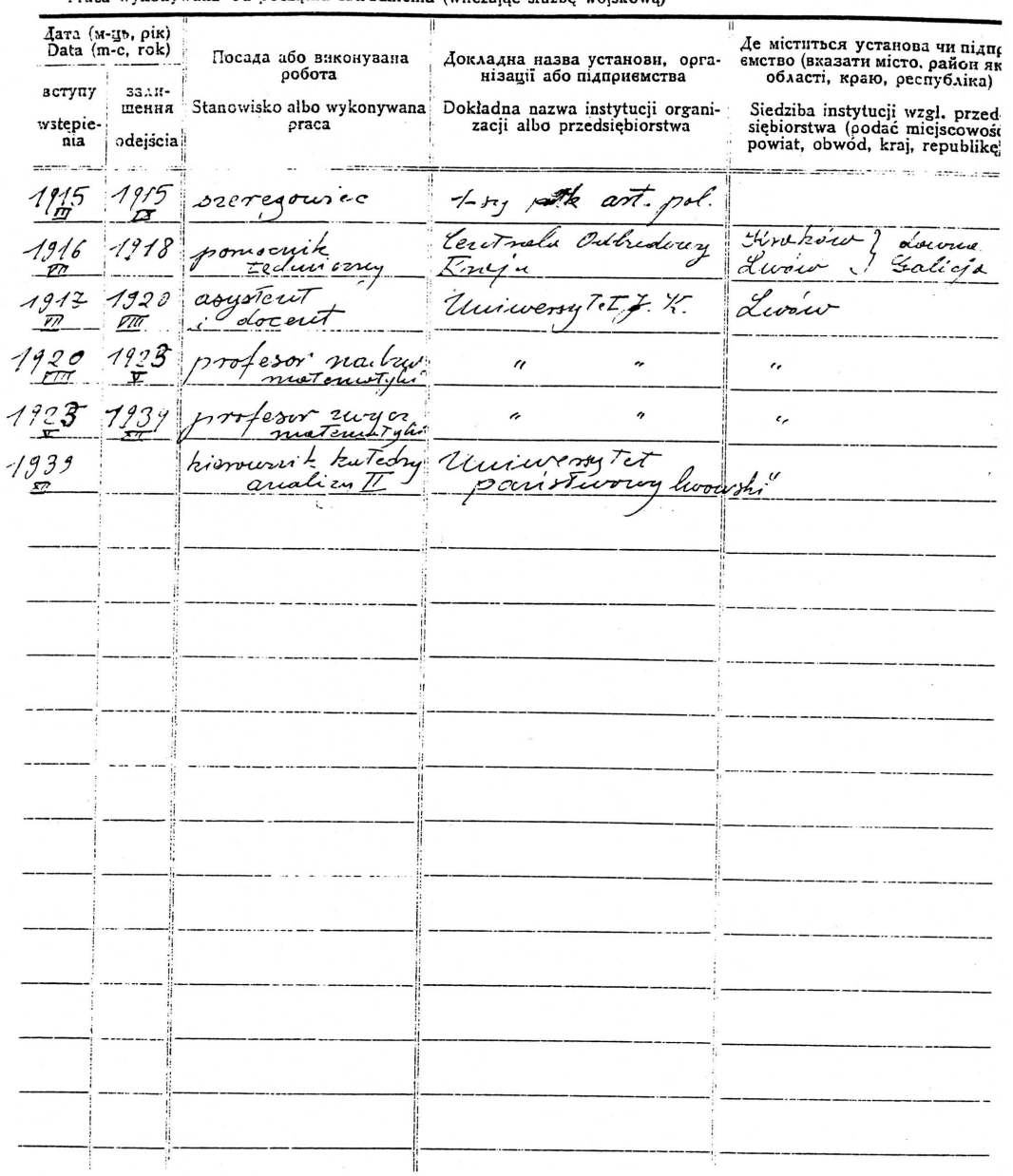

11. Робота за суміснидтзом (в момент заповнення особ. листка) Rownoczesna inna praca ( $w$ chwili wypelnienia karty osobowej)

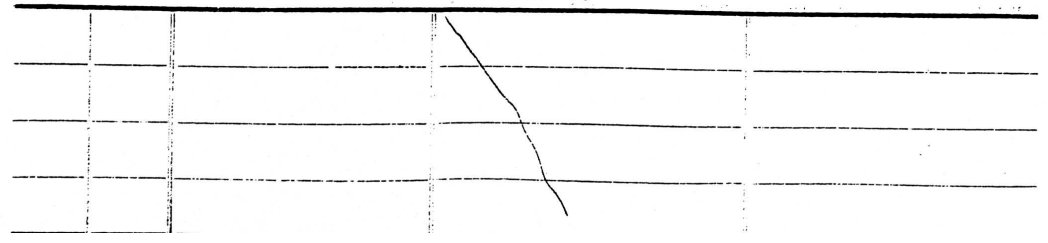

Fig. 2. Document 2 
12. Знання чужоземних мов і мов народів CPCP.

Znajomośc obcych języków $i$ języków narodów Z.S.R.R.

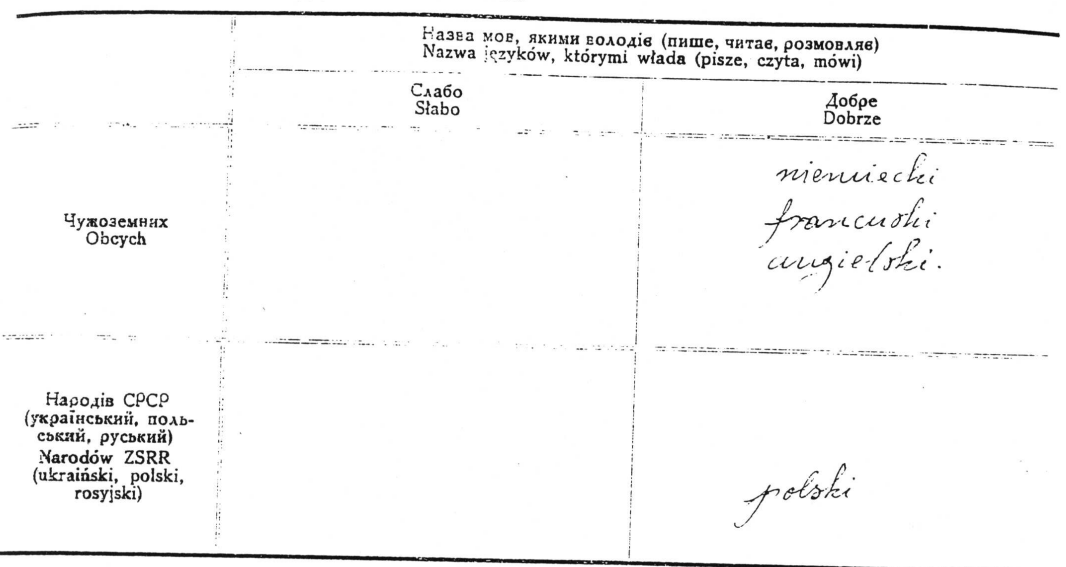

13. Служба в арміях

Siużba wojskowa

$$
\begin{aligned}
& \text { в арміï } 3 \\
& \text { vojsku od }
\end{aligned}
$$

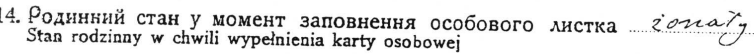

15. Жомашиій адрес

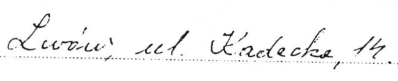

2?. $\overline{x i 1}$

(data заповнення)

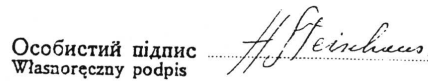

Підпис т.

Podpis t.

свідиу.

stwierdzam.

M. п.

M. P.

3 оригіналом згідно:

Посада і підпис особи, яка знімала копію

Stanowisko i podpis osoby, sporzạdzajacej kopie

Fig. 3. Document 3 


\section{References}

[1] H.Steinhaus, Kalejdoskop matematyczny [Mathematical Snapshots], 2nd ed., Państwowe Zakłady Wydawnictw Szkolnych, Warsaw 1954 (in Polish); English transl.: 2nd ed., Warsaw 1950; Russian transl.: Г. Штейнгауз, Математический Калейдоскоп, Наука, Москва 1987, $160 \mathrm{c}$.

[2] Г. Штейнгауз, Задачи и размышления [Problems and reflections], Мир, Москва 1974, 400 c. (in Russian).

[3] H.Steinhaus, Sto zadań [One Hundred Problems], Państwowe Wydawnictwo Naukowe, Warszawa 1958; Russian transl.: Г. Штейнгауз, Сто задач, Мир, Москва 1986, 144 с.

[4] A. Kosiński, On a problem of Steinhaus, Fund. Math. 46 (1958), 47-59.

[5] Yu. B. Zelinskii, On some problems of Kosiński, Ukrainian Math. J. 27 (1975), 510-516.

[6] Yu. B. Zelinskii, Application of sheaf theory to the investigation of continuous mappings, Tenth Math. Summer School (Kaciveli/Nalchik 1972), Inst. Mat. Akad. Nauk Ukrain. SSR, Kiev 1974, pp. 290-307 (in Russian).

[7] Yu. B. Zelinskii, On n-admisible multivalued mappings, Metric Questions in the Theory of Functions and Mappings, Vyp. 7, Naukova Dumka, Kiev 1975, pp.61-83 (in Russian).

[8] Yu. B. Zelinskii, Multivalued Mappings in Analysis, Naukova Dumka, Kiev 1993, 264 pp. (in Russian).

[9] Yu. B. Zelinskii, On multiplicity of continuous mappings of domains, Ukrainian Math. J. 57 (2005), 554-558 (in Russian). 